\title{
Foreign Tourist's Perception towards Balinese Traditional Food Provided by Restaurants in Bali
}

\author{
Made Arya Astina, Ketut Muliadiasa \\ Sekolah Tinggi Pariwisata Bali Internasional \\ Denpasar, Indonesia \\ aryaastina.made@gmail.com
}

\begin{abstract}
Food is a significant aspect of the tourist's experience of a destination. Bali is one of the most popular tourist's destination in the world. This research is about foreign tourist's perception towards balinese traditional food The aims of this research are (1) to know about foreign tourist's perception towards Balinese Traditional Food that provided in several restaurants in Southern part of Bali island (2) to know the effort needed to make Balinese Traditional Food to be favored to the foreign tourists. The research is conducted on July up to September 2016, by taking samples in restaurants at some tourism destination in Bali (Sanur, Kuta, Nusa Dua). This research has done in Sanur beach, Kuta Beach, and Nusa Dua beach because these area are the most popular place to be visited by the foreign tourist. Data collection method were conducted through observation, interview, library study and also by distributing questionaire in those area. Purposive Sampling Technique was applied in this research to determining the respondents. All data analyzed by using descriptive analysis technique which were spelt out, which later on could provide a holistic information in accordance with the foreign tourist's perception towards Balinese Traditional Food and the effort needed to make Balinese Traditional Food to be favored. There are several aspects on food to be analized in this study those are the taste, hygiene and sanitation, price, velocity of service, presentation, and supporting facilities. Based on this research, the aspect of taste, hygiene and sanitation, and presentation are the point that need to be improved. The perception towards Balinese Traditional Food in other aspect (price, velocity of service, and supporting facilities) is good. The effort needed to make Balinese Traditional Food to be well known are (1) the taste of food (not spicy) should be more acceptable by the foreign tourist, (2) the food sould be prepared and presented considering aspects of hygiene and sanitation.
\end{abstract} food.

Keywords - Foreign Tourist Perception, Balinese traditional

\section{INTRODUCTION}

The island of Bali as a tourism destination is known by various names, such as the island of God, the last paradise, and the island of thousand temples. This island is very rich in its culture. Besides, this island also has a very beautiful natural scenery. Social tradition of Balinese inspired by Hindu religion becomes the main attraction of the tourism to come to this island. The infrastructures that support tourism have been built on this beautiful island. International airport, five-star hotels, restaurants, bars, spas and many other supporting facilities have been built. The uniqueness of Balinese culture, and beautiful scenery, as well as adequate supporting of tourism facilities on the island causes the island of Bali is well known and visited by many foreign tourists.

Cultural tourism is a type of tourism that is developed in the island of Bali. Various types of the traditional uniqueness of Balinese people are expected to be maintained and developed so it can attract the tourists to come to this island. The different types of dances, processions of Hindu religious ceremonies, and various social culture of Hinduism in Bali is the main attraction for tourists. One component of the culture on the island of Bali which is expected to make tourists come to this island is the traditional Balinese food.

Food is an important aspect in tourism. The island of Bali which is developing the concept of cultural tourism is expected to develop traditional or local foods to be used to attract the tourists to come to the island of Bali. Efforts should be made to make the traditional Balinese food is not only known but also favored by travelers. Star hotels, restaurants and cafe in Bali now offer Balinese traditional food to foreign tourists. However, most of the main aim of foreign tourists coming to Bali are not to find Balinese traditional foods as part of their holiday experience. Culinary tourism is a type of tourism should be developed in Bali to make the tourists experience more various. Traditional Balinese food that is rich in herbs and spices can be expected to be a potential that is difficult to be imitated by other countries in the world.

To develop culinary tourism on this island of God, various efforts are needed. One of the efforts is to do a study related to the perception of tourists to Balinese traditional food. Based on the above explanation, the analysis of foreign tourist perception towards traditional Balinese food offered in restaurants in Bali needs to be done. By knowing the perception of tourists to the traditional Balinese food, the efforts to make traditional Balinese food favored by foreign tourists can be identified.

\section{METHODS}

This research was conducted in some tourist areas in Bali. They are Sanur, Kuta and Nusa Dua beach area. Research that took place in several restaurants in the tourist area in Bali was conducted from July to September 2016. The variables in this 
study were (1) the perception of foreign tourists to the traditional Balinese food offered in the restaurant in Bali, and ( 2) effort that can be done to make the traditional Balinese food favored by foreign tourists.

The types of data used in this research is quantitative data and qualitative data. While the source of data used in this research was primary data that obtained directly from the respondent (tourists) and secondary data that was arranged by other parties, such as the Department of Tourism and Hotel and Restaurant Association of Indonesia-Bali

Determination of the respondents using purposive sampling by interviewing people who are supposed to know the problems and quota sampling technique aimed at foreign tourists who met while research is conducted

The data in this study were collected through techniques: 1) observations on matters related to traditional Balinese food are offered at the location; 2) structured interviews conducted using instruments as a guidance. In-depth interviews are also conducted in this study to know in detail the primary data; 3) questionnaire given to the foreign tourists who visit the restaurant. The collected data were analyzed with descriptive qualitative analysis, where this technique is used to analyze and interpret qualitative data so as to describe and obtain conclusions about the perception of foreign tourists to the traditional Balinese food.

The collected data were then analyzed with descriptive qualitative analysis, where this technique was used to analyze and interpret qualitative data so that the researcher could describe and obtain the conclusions about the perception of foreign tourists to the traditional Balinese food offered in some tourist areas in Bali

\section{RESULT AND DISCUSSION}

Restaurants that offer the traditional Balinese food available in several places in Bali. There are several restaurants in the area of Sanur, Kuta and Nusa Dua which were used as a place of research. The distribution of the number of restaurants serving in three regions as in Table 1. Number of restaurants offer were used as a place of research are as follows: 3 (three) restaurants at Sanur Beach restaurant, four (4) restaurants at Kuta beach, 2 (two) restaurants at Nusa Dua.

TABLE I. RESTAURANTS OFFER TRADITIONAL BALINESE

\begin{tabular}{lllll}
\hline No & Area & $\begin{array}{c}\text { Number of } \\
\text { Restaurant }\end{array}$ & Respondent & Informan \\
\hline 1 & Sanur & 3 & 30 & 6 \\
2 & Kuta & 4 & 40 & 8 \\
3 & Nusa Dua & 2 & 20 & 4 \\
\hline & Total & 9 & 90 & 18 \\
\hline
\end{tabular}

The traditional Balinese food are served in some tourist areas in Bali, in general it look pretty but the difference is the presentation and variation of seasoning. The types of food that served are: 1) soup (fish soup, gerangasem); 2) the main meal (white rice, brown rice, yellow rice, porridge / bubuh, tipat; 3 ) vegetables (jukut urab, serombotan, pelecing, lawar; 4) the side dishes (Be guling, betutu, tum, pepesan , urutan / sausage Bali, be nyatnyat, calon, mix satay (meat satay, satay nyuh etc.), lindung; 5) snack (tape, jaje uli, bubuh sumsum, bubuh ketan,lukis, laklak, giling-giling, klepon, sumping, apem etc.)

From the observation, interviews and the submission of the questionnaire obtained the following data:

a. Perception of foreign tourists to the taste of food.

Based on the questionnaires distributed, obtained data on the perception of tourists to the taste of traditional Balinese foods are offered in several tourism destinations in Bali. 31\% of respondents stated 'good', 49\% of respondents stated 'fair', $20 \%$ respondents stated 'poor'.

Based on that information, the taste of traditional Balinese food which are offered to foreign tourists in Bali need to be modified. From interviews with some tourists obtained information that most of the traditional Balinese food on offer has a spicy flavor, and less combinations.

b. Tourist perception of the hygiene and sanitation.

From the aspect of hygiene and sanitation, perception of foreign tourists in the destination to the Balinese food as follow : $12 \%$ of respondents stated 'good', $46 \%$ of respondents stated 'fair', $42 \%$ respondents stated 'poor'.

Based on the interviews and observations obtained information that the traditional Balinese food processed in a way that is less attention of aspects of hygiene and sanitation. Cutting board made of wood, food prepared by personnel who are less concerned about the cleanliness.

\section{c. Tourists perception of the Food Price}

In addition to taste and hygiene and sanitation, the price aspect is one of travelers consideration when deciding to buy traditional Balinese food. The perception of foreign tourists to the price of a traditional Balinese food offered at some tourist destinations are as follows: $81 \%$ of respondents stated 'very good', 19\% respondents stated 'good'.

\section{d. Tourists perception of the Presentation of Food}

the tourist perception to the presentation of the tradisioanal food of Bali served in restaurants in tourist destinations are as follows: $7 \%$ of respondents stated 'good', $84 \%$ of respondents stated 'fair', 9\% respondents stated 'fair'.

Based on interviews and observations, the presentation of traditional Balinese food could be improved by considering variation of color, texture, ingredientsstated and the type of serving dish

\section{e. Tourist perception of the Service Staff}

It was found that most of the tourists stated the service provided was good. $86 \%$ of respondents stated 'good', 14\% of respondents stated 'fair'.

Based on interviews and observations, most of the waitresses in tourist destinations are already doing service well. The frienliness of Balinese people need to be maintained. 


\section{f. Tourists Perception to Supporting Facilities}

Supporting facilities such as parking area, toilets, dining facilities are the things that need to be considered for the management of restaurant. The perception of tourists to supporting facilities provided by restaurants that offer traditional Balinese food are as follows: $82 \%$ of respondents stated 'good', $18 \%$ respondents stated 'fair'.

From the interviews and the observations, it was found that supporting facilities of restaurants were quite good, but at some restaurants were still found that the toilets were not clean.

\section{CONCLUSION}

From the six criterias used to assess the perception of foreign tourists to the traditional Balinese food, it can be concluded that the tourists perception to the aspects of taste, hygiene and sanitation, and food presentation needs to be improved. While pricing, service and supporting facilities were already stated 'good'.

To make the traditional Balinese food be favored by foreign tourists, the traditional Balinese food needs to be modified by the following way: a. Reducing spicy flavor

b. Food preparation process and serving should considering the aspects of hygiene and sanitation

c. The presentation of traditional Balinese food needs to be plated better, for example by considering variations color, taste, texture, ingredients.

\section{REFERENCE}

Chesser, Jerald W. (2003). The Art and Science of Culinary Preparation. Florida. The Education Institute of The American Culinary Federation, Inc.

Kivela, Jaksa. (1994). Menu Planning for the Hospitality Industry. Melbourne. Hospitality Press.

Kusmayadi, \& Endar Sugiarto. (2000). Metodologi Penelitian Dalam Bidang Kepariwisataan. Jakarta: Gramedia Pustaka Utama.

Salah Wahab., Crampon L.J., \& Rothfield., L.M. (1997). Pemasaran Pariwisata. Jakarta : Pradnya Paramita.

Soekadijo. (2000). Anatomi Pariwisata. Jakarta, Gramedia.

Sugiyono. (2009). Metode Penelitian Kuantitatif, Kualitatif dan $R \& D$. Bandung: Alfabeta 